\title{
Tissue Culture Infection Dose
}

National Cancer Institute

\section{Source}

National Cancer Institute. Tissue Culture Infection Dose. NCI Thesaurus. Code C67449.

A quantity of a pathogen required to infect a tissue culture with measurable cytopathic effects. 